\title{
Peran Silikon dalam Meningkatkan Pertumbuhan dan Kadar Klorofil Padi yang Tercekam Kadmium
}

\author{
Rita Ariyana Nur Khasanah ${ }^{1,2^{*}}$, Diah Rachmawati ${ }^{3}$ \\ ${ }^{1}$ Program Studi Pendidikan Biologi, Fakultas Sains dan Teknologi UIN Walisongo Semarang, 50181- \\ Indonesia \\ ${ }^{2}$ Program Pascasarjana Biologi, Fakultas Biologi Universitas Gadjah Mada, 55281- Indonesia \\ E-mail: ritaariyana@walisongo.ac.id \\ ${ }^{3}$ Laboratorium Fisiologi Tumbuhan, Fakultas Biologi, Universitas Gadjah Mada, Yogyakarta 55281- \\ Indonesia, Email: drachmawati@ugm.ac.id
}

\begin{abstract}
Cadmium (Cd) accumulation and pollution in soil is a major problem for agriculture because it is toxic for many crops. Several works reported that negative effects of $\mathrm{Cd}$ on plants can be mitigated by the addition of beneficial elements, such as silicone (Si) into the soil. Nevertheless, the effect of Si to mitigate Cd toxicity in 'Cempo Merah' rice has never been evaluated. The aim of this study is to analyze the role of Si in the growth and chlorophyll content of 'Cempo Merah' rice exposed to Cd stress. This research used a Complete Randomized Design with two variables, namely $3 \mathrm{CdSO}_{4} \cdot \mathrm{H}_{2} \mathrm{O}$ and $\mathrm{CaSiO}_{3}$ (each with 0,50 and $100 \mathrm{mg} \cdot \mathrm{kg}^{-1}$ ) concentrations, using three replicates for each treatment. The vegetative growths (plant height, number of leaves and tillers, fresh weight) and chlorophyll content were recorded and analyzed using ANOVA and Duncan's test at $\mathrm{p} \leq 0.05$. Our results show that $\mathrm{Cd}$ exposure leads to reduced vegetative growth and chlorophyll content in 'Cempo Merah' rice, however application of Si into the soil (100 mg.kg- $)$ can effectively mitigate $\mathrm{Cd}$ toxicity and promotes growth and chlorophyll production in the stressed plants.
\end{abstract}

Key words: cadmium, chlorophyll, growth, silicon, rice 'Cempo Merah'

\begin{abstract}
Abstrak
Akumulasi dan pencemaran kadmium (Cd) di daerah persawahan menjadi masalah yang besar di bidang pertanian karena $\mathrm{Cd}$ bersifat toksik pada beberapa tanaman pangan. Beberapa studi telah melaporkan mengenai dampak negative $\mathrm{Cd}$ pada tanaman dapat dikurangi dengan penambahan unsur benefisial silikon (Si) pada tanah. Namun, pengaruh Si untuk mengurangi toksisitas Cd pada padi 'Cempo Merah' belum pernah dievaluasi. Tujuan dari penelitian ini yaitu untuk menganalisis peran Si dalam pertumbuhan dan kandungan klorofil pada padi 'Cempo Merah' yang tercekam Cd. Penelitian ini menggunakan desain Rancangan Acak Lengkap 2 variabel, yakni perlakuan $3 \mathrm{CdSO}_{4} \cdot \mathrm{H}_{2} \mathrm{O}$ dan $\mathrm{CaSiO}_{3}$ (masing-masing dengan konsentrasi 0, 50, dan 100 mg.kg-1 tanah), dengan 3 kali ulangan untuk setiap perlakuan. Pertumbuhan vegetatif (tinggi tanaman, jumlah daun, jumlah anakan, berat basah) serta kadar klorofil diamati dan dianalisis menggunakan ANOVA (analisis sidik ragam) dan uji DMRT (Duncan Multiple Range Test) pada $\mathrm{p} \leq 0,05$. Hasil penelitian menunjukkan bahwa paparan $\mathrm{Cd}$ menyebabkan pertumbuhan vegetatif dan kadar klorofil padi 'Cempo Merah' menurun, namun aplikasi Si (100 mg.kg-1 tanah) secara efektif mengurangi toksisitas Cd dan mendukung pertumbuhan dan produksi kadar klorofil padi 'Cempo Merah' yang tercekam Cd.
\end{abstract}

Kata kunci: kadmium, klorofil, pertumbuhan, silikon, padi ‘Cempo Merah'

\section{Pendahuluan}

Pencemaran logam berat kadmium (Cd) di area persawahan menjadi masalah lingkungan yang serius di berbagai daerah. Polutan Cd dalam konsentrasi yang tinggi dapat menyebabkan toksisitas pada tanaman pangan (Nazar et al., 2012). Penggunaan pupuk fosfat anorganik disebut sebagai sumber utama kontaminasi Cd, selain berasal dari limbah pabrik industri yang dibuang ke lingkungan dan mencemari sistem irigasi (Robertsa, 2014). Pencemaran Cd pada sistem irigasi pertanian telah terjadi di beberapa daerah di Indonesia. Wardhani et al. (2017) melaporkan adanya kasus pencemaran $\mathrm{Cd}$ di waduk Saguling yang mana sumber utama airnya 
berasal dari sungai Citarum, Jawa Barat. Konsentrasi rata-rata $\mathrm{Cd}$ di sedimen waduk Saguling dari musim kemarau hingga musim penghujan tahun 2015 mengalami kenaikan dari 13,54 mg.kg-1 menjadi 21,08 mg.kg-1. Konsentrasi tersebut melebihi baku mutu kualitas sedimen yang berlaku di Australia dan New Zaeland (1,5 mg.kg-1) sehingga dapat dikatakan bahwa waduk Saguling tergolong terkontaminasi sangat tinggi. Pencemaran Cd juga terjadi di perairan daerah aliran sungai (DAS) Grindulu di Pacitan, Jawa Timur, yang mana konsentrasi $\mathrm{Cd}$ di daerah tengah dan hilir diketahui sebesar (0,0104-0,024) mg. $\mathrm{L}^{-1}$, melebihi ambang batas baku mutu 0,01 mg.L $L^{-1}$ menurut PP No. 82 tahun 2001 tentang Pengelolaan Kualitas Air dan Pengendalian Pencemaran Air (Wijayanti, 2017). Pencemaran Cd juga mungkin terjadi di daerah lainnya di Indonesia dan menjadi isu penting baik di bidang pertanian maupun kesehatan karena sifatnya yang toksik.

Pencemaran logam berat $\mathrm{Cd}$ dapat memberikan dampak yang merugikan untuk tanaman yang tidak toleran. Pada konsentrasi tinggi, Cd dapat menghambat pertumbuhan dan perkembangan tanaman (Nazar et al., 2012). Dalin et al. (2011) melaporkan bahwa serapan Cd pada tanaman sorgum dengan perlakuan 50 dan 100 mg.kg-1 tanah secara signifikan menekan pertumbuhan. Dampak negatif $\mathrm{Cd}$ terhadap pertumbuhan juga teramati pada tanaman strowberry (Fragaria x ananassa cv. Camarosa) (Muradoglu et al., 2015) dan kedelai (Glycine max (L.) Merr.) cv. Shan (Xue et al., 2014). Terhambatnya pertumbuhan tanaman tersebut berhubungan dengan menurunnya sintesis klorofil dan laju fotosintesis. Selain mengganggu proses fotosintesis, ion $\mathrm{Cd}^{2+}$ dapat menginduksi stress oksidatif secara tidak langsung dengan mempengaruhi sistem petahanan antioksidan, mengganggu sistem transpor elektron (STE) dan menginduksi peroksidasi lipid (Hossain et al., 2012).

Penelitian ini menggunakan tanaman padi (Oryza sativa L.) 'Cempo Merah' yang merupakan kultivar asli dari kabupaten Sleman, Yogyakarta. Secara umum, tanaman padi (Gramineae) memiliki karakteriktis morfologis seperti tipe batang calmus; tipe daun linearis; sistem perakaran serabut; tipe bunga malai bercabang atau bulir majemuk, dengan bulir kecil dan pipih, terletak pada ujung batang; tiap bunga tersusun atas 1 palea inferior, 2 palea superior, 2 lodiculae, 3 benang sari, dan putik dengan kepala putik berbentuk bulu; tipe buah karyopsis (kering) serta tanaman padi dapat membentuk beberapa anakan majemuk (Tjitrosoepomo, 2007). Padi 'Cempo Merah' memiliki tinggi $\pm 135,83 \mathrm{~cm}$; umur tanaman \pm 166 hari setelah semai; umur berbunga \pm 81 hari setelah semai, dan kepala putik berwarna ungu. Selain itu, produktivitas gabah 'Cempo Merah' terdiri dari bobot gabah isi per malai sebanyak 3,58 gram; jumlah gabah isi per malai sebanyak 141; dan bobot gabah isi per rumpun sebanyak 81,16 gram (Supriyanti et al., 2015). Padi ini disebut sebagai padi sawah yang tidak tahan kering (Rachmawati et al., 2018) dan siklus hidupnya bergantung pada sistem irigasi, sehingga rentan terkena paparan logam berat.

Farooq et al. (2016) dan Tripathi et al. (2012) telah menyelidiki peran unsur benefisial silikon (Si) dalam mengurangi toksisitas $\mathrm{Cd}$ pada tanaman padi serta menunjukkan peran Si dalam meningkatkan pertumbuhan padi. Si merupakan unsur kedua terbanyak di alam setelah oksigen (0) dalam kerak bumi (Tubana et al., 2016). Konsentrasi rata-rata Si di litosfer sekitar 28\% sementara di tanah berkisar antara 23-35\% (Rao \& Susmitha, 2017). Si yang umum tersedia di tanah dan dapat diserap oleh akar tanaman dalam bentuk asam silikat $\left(\mathrm{H}_{4} \mathrm{SiO}_{4}\right)$ (Tubana et al., 2016). Selain dari abu sekam padi (Rachmawati et al., 2018), penambahan unsur Si pada tanah dapat diperoleh dari penggunaan pupuk silikat anorganik seperti sodium silikat $\left(\mathrm{Na}_{2} \mathrm{SiO}_{3}\right)$ dan kalsium silikat $\left(\mathrm{CaSiO}_{3}\right.$ ) (Kaushik \& Saini, 2019; Lu et al., 2017). Peran Si dalam mengurangi toksisitas Cd pada padi 'Cempo Merah' belum banyak diteliti. Oleh karena itu, tujuan penelitian ini yaitu untuk mengkaji peran Si yang bersumber dari pupuk kalsium silikat $\left(\mathrm{CaSiO}_{3}\right)$ dalam meningkatkan pertumbuhan vegetatif dan kadar klorofil padi 'Cempo Merah' yang tercekam logam berat Cd.

\section{Metode Penelitian}

\section{Desain Penelitian}

Penelitian ini dilaksanakan di green house Laboratorium Ilmu Tanah, Fakultas Pertanian, Universitas Gadjah Mada. Penelitian ini (mulai dari tahap persiapan media, penanaman, hingga pengambilan data) berlangsung sejak bulan Agustus 2017- Februari 2018. Penelitian ini menggunakan desain Rancangan Acak Lengkap (RAL) dua faktorial, yaitu Cd (3CdSO4.H2O) dan Si (CaSiO3) dengan dosis yang sama $(0,50$, dan 100$)$ mg.kg-1 tanah, dengan 3 kali ulangan. Dosis Cd 100 mg.kg-1 karena telah dilaporkan dapat menyebabkan toksisitas pada tanaman sorgum (Da-lin et al., 2011) dan sawi India (Brassica juncea) (Irfan et al., 2014), sementara dosis Si 100 mg.kg-1 dipilih karena dilaporkan dapat mengurangi dampak toksisitas Cd pada tanaman padi (Lin et al., 2016). Dengan demikian, terdapat 9 perlakuan kombinasi, terdiri dari: 1) Si 0 Cd 0 ; 2) Si 0 Cd 50; 3) Si 0 Cd 100; 4) Si 50 Cd 0; 5) Si 50 Cd 
50; 6) Si 50 Cd 100; 7) Si 100 Cd 0; 8) Si 100 Cd 50; dan 9) Si $100 \mathrm{Cd} 100$ dalam mg.kg-1 tanah.

\section{Prosedur Kerja}

Benih padi direndam di dalam air selama 24 jam. Benih padi yang tenggelam dipilih untuk dikecambahkan pada kapas yang dibasahi air (selama 2 hari). Selanjutnya, benih padi yang telah muncul radikula ditanam pada gelas plastik yang berisi tanah dan dibiarkan tumbuh. Kecambah umur 14 hari (tinggi $\pm 32 \mathrm{~cm}$ dan jumlah daun 3 ) dipindahkan ke dalam polybag yang berisi $3,5 \mathrm{~kg}$ tanah sawah (dengan tekstur tanah Silt loam soil) (pH 6.8). Analisis kimia tanah ditunjukan pada Tabel 1. Pupuk silikat ditambahkan pada medium tanah pada 1 minggu sebelum kecambah padi dipindahkan ke polybag. Selain itu, pupuk urea (120 mg.kg-1 tanah), SP36 (20 mg.kg- ${ }^{-1}$ tanah), dan $\mathrm{KCl}(20$ mg.kg-1 tanah) diberikan untuk memberikan nutrisi pada pertumbuhan awal padi. Penyiraman $( \pm 300 \mathrm{~mL}$ air $)$ dan pembersian gulma dilakukan setiap 2 hari sekali. Padi dipelihara di dalam greenhouse $\left(23^{\circ} \mathrm{C}-32^{\circ} \mathrm{C}\right.$, kelembaban $80 \%$ $90 \%$ ) selama \pm 8 minggu.

Tabel 1. Parameter tanah

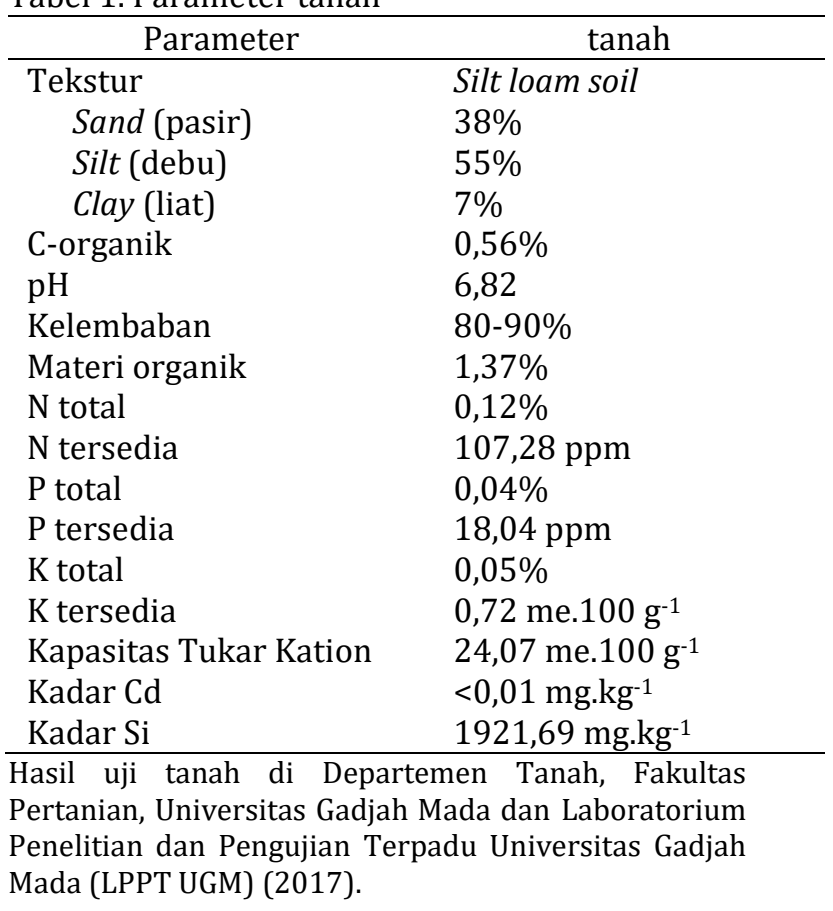

\section{Pengukuran Parameter Pertumbuhan}

Parameter pertumbuhan vegetatif yang diukur meliputi tinggi tanaman, jumlah daun dan jumlah anakan. Tinggi tanaman diukur mulai dari pangkal batang di atas permukaan tanah sampai pucuk daun tertinggi menggunakan mistar. Selain itu, parameter pertumbuhan lainnya yakni berat basah akar dan tajuk diukur pada 8 MST, menggunakan timbangan digital analitik.

\section{Pengukuran Kadar Klorofil}

Sebanyak 0,1 g daun segar digerus dengan mortar dan dilarutkan dalam $10 \mathrm{~mL}$ aseton $80 \%$, selanjutnya ekstrak disaring menggunakan kertas Whatman no. 1, kemudian filtrat dimasukkan ke dalam kuvet kuarsa. Nilai optical density (OD) filtrate klorofil dibaca menggunakan spektrofotometer (Genesis UV-Scanning Thermo Scientific), pada panjang gelombang $(\lambda) 646 \mathrm{~nm}$ dan $663 \mathrm{~nm}$. Kadar klorofil dihitung menggunakan persamaan dari Lichtenthaler \& Wellburn (1983) (Grzeszczuk et al., 2018). Selanjutnya, kadar klorofil (mg.L $\mathrm{L}^{-1}$ ) dikonversi ke dalam satuan (mg.g$\left.{ }^{1} \mathrm{BB}\right)$.

Klorofil a $=\left(12,21 \times\right.$ A663 - 2,81 x A646) mg. $\mathrm{L}^{-1}$ Klorofil $b=(20,13 \times$ A646 - 5,03 $\times$ A663 $) \mathrm{mg} \cdot \mathrm{L}^{-1}$ Klorofil total $=\left(17,32 \times \mathrm{A}_{646}+7,18 \times \mathrm{A}_{663}\right) \mathrm{mg} \cdot \mathrm{L}^{-1}$

Keterangan:

$\mathrm{A}_{646}=$ absorbansi pada $\lambda 646 \mathrm{~nm}$

$A_{663}=$ absorbansi pada $\lambda 663 \mathrm{~nm}$

$\mathrm{BB}=$ berat basah

\section{Analisis Data}

Data penelitian yang diperoleh dianalisis sidik ragam menggunakan Analysis of Variance (ANOVA) two way dan dilanjutkan dengan Duncan's Multiple Range Test (DMRT) pada taraf kepercayaan $95 \%$ pada $\mathrm{p} \leq 0,05$ menggunakan program SPSS18.

\section{Hasil Penelitian dan Pembahasan}

Cekaman Cd (100 mg.kg-1 tanah) yang diberikan pada medium tanah menghambat pertumbuhan vegetatif (tinggi tanaman, jumlah daun, jumlah anakan, dan berat basah) padi dibandingkan kontrol, namun aplikasi Si pada medium pertumbuhan meningkatkan pertumbuhan padi 'Cempo Merah' yang tercekam Cd $(p \leq 0,05)$ (Tabel 2 dan Tabel 3).

Tabel 2. Pertumbuhan padi 'Cempo Merah' dengan perlakuan Si dan Cd 


\begin{tabular}{lccc}
\hline $\begin{array}{c}\text { Perlakuan } \\
\text { (mg.kg-1) }\end{array}$ & $\begin{array}{c}\text { Tinggi } \\
\text { tanaman } \\
(\mathrm{cm})\end{array}$ & $\begin{array}{c}\text { Jumlah } \\
\text { daun }\end{array}$ & $\begin{array}{c}\text { Jumlah } \\
\text { anakan }\end{array}$ \\
\hline Si 0 Cd 0 & $103,5 \pm 1,32^{\mathrm{d}}$ & $34,33^{\mathrm{cd}}$ & $6,7 \mathrm{~b}$ \\
Si 0 Cd 50 & $94,7 \pm 0,72^{\mathrm{ab}}$ & $30,00^{\mathrm{b}}$ & $5^{\mathrm{a}}$ \\
Si 0 Cd 100 & $92,9 \pm 1,36^{\mathrm{a}}$ & $27,67^{\mathrm{a}}$ & $5^{\mathrm{a}}$ \\
Si 50 Cd 0 & $104,2 \pm 1,08^{\mathrm{d}}$ & $35,00^{\mathrm{cd}}$ & $7^{\mathrm{bc}}$ \\
Si 50 Cd 50 & $95,0 \pm 2,12^{\mathrm{ab}}$ & $33,67^{\mathrm{cd}}$ & $7,3^{\mathrm{cd}}$ \\
Si 50 Cd 100 & $95,5 \pm 0,95^{\mathrm{ab}}$ & $33,00^{\mathrm{c}}$ & $7^{\mathrm{bc}}$ \\
Si 100 Cd 0 & $107,9 \pm 1,32^{\mathrm{e}}$ & $36,00^{\mathrm{d}}$ & $8^{\mathrm{e}}$ \\
Si 100 Cd 50 & $98,4 \pm 2,44 \mathrm{c}$ & $34,67^{\mathrm{cd}}$ & $7,7^{\mathrm{de}}$ \\
Si 100 Cd 100 & $96,9 \pm 0,85^{\mathrm{bc}}$ & $34,33^{\mathrm{cd}}$ & $7,3^{\mathrm{cde}}$ \\
\hline
\end{tabular}

Ket. Angka pada kolom dan baris diikuti huruf yang sama menunjukkan tidak berbeda nyata berdasarkan uji DMRT $(\mathrm{p} \geq 0,05)(\mathrm{r}=3)$.

Kadmium (Cd) merupakan unsur logam berat toksik yang mana dalam konsentrasi yang tinggi dapat mengancam kelangsungan hidup tanaman (Irfan et al., 2014). Sifatnya yang mobile dan mudah diserap oleh akar tanaman (Nazar et al., 2012) mungkin menjadi penyebab utama menurunnya pertumbuhan padi 'Cempo Merah' yang diberi cekaman $\mathrm{Cd}$. Absorbsi $\mathrm{Cd}$ dapat menyebabkan gangguan absorbsi, transpor dan distribusi nutrien lainnya, seperti ion $\mathrm{K}^{+}, \mathrm{Ca}^{2+}$, dan $\mathrm{Mg}^{2+}$ yang penting dibutuhkan untuk pertumbuhan dan perkembangan tanaman (Robertsa, 2014; Nazar et al., 2012). Guo et al. (2017) melaporkan adanya gangguan penyerapan ion $\mathrm{K}^{+}, \mathrm{Fe}^{2+}, \mathrm{Zn}^{2+}, \mathrm{Mn}^{2+}$ dan $\mathrm{Mg}^{2+}$ pada Iris lactea, yang diduga terjadi karena adanya kompetisi absorbsi antara ion $\mathrm{Cd}^{2+}$ dengan ion mineral lain seperti ion $\mathrm{Ca}^{2+}, \mathrm{Mg}^{2+}$, dan $\mathrm{Fe}^{2+}$. Sebagaimana diketahui bahwa umumnya membran akar tidak terdapat transporter khusus untuk Cd. Ion $\mathrm{Cd}^{2+}$ dapat masuk ke dalam sel-sel akar tanaman melalui transporter nutrien lain dengan cara berkompetisi dengan nutrient-nutrien tersebut. Contohnya, Ion $\mathrm{Cd}^{2+}$ dapat masuk ke dalam sel akar padi melalui transporter OsiRT1 (ironregulated transporter 1) dengan cara berkompetisi dengan ion $\mathrm{Fe}^{2+}$ dan transporter OsNRAMP5 (natural resistance-associated macrophage protein 5) dengan cara berkompetisi dengan ion $\mathrm{Zn}^{2+}$ dan ion $\mathrm{Mn}^{2+}$ atau masuk melalui $\mathrm{Ca}^{2+}$ channel dengan cara berkompetisi dengan ion $\mathrm{Ca}^{2+}$ (Nazar et al., 2012; Gao et al., 2016). Cekaman Cd juga dilaporkan dapat menyebabkan gangguan metabolisme pada level seluler yang melibatkan reaksi enzimatis, seperti fotosintesis, respirasi, dan lain-lain (Nazar et al., 2012). Dengan demikian, pertumbuhan tanaman menjadi menurun.
Tabel 3. Berat basah tajuk dan akar padi 'Cempo Merah' dengan perlakuan Si dan Cd

\begin{tabular}{|c|c|c|}
\hline \multirow{2}{*}{$\begin{array}{c}\text { Perlakuan } \\
\left(\mathrm{mg} \mathrm{kg}^{-1}\right)\end{array}$} & \multicolumn{2}{|c|}{ Berat basah (g) } \\
\hline & Tajuk & Akar \\
\hline Si 0 Cd 0 & $64,51 \pm 0,29$ de & $13,68 \pm 0,22^{d}$ \\
\hline Si 0 Cd 50 & $57,29 \pm 0,96^{b}$ & $10,78 \pm 0,67 b$ \\
\hline Si 0 Cd 100 & $52,60 \pm 1,69 a$ & $8,81 \pm 0,47 a$ \\
\hline Si 50 Cd 0 & $66,46 \pm 0,30^{\mathrm{ef}}$ & $14,22 \pm 0,16^{\mathrm{de}}$ \\
\hline Si 50 Cd 50 & $63,88 \pm 1,93^{d}$ & $12,02 \pm 0,15^{c}$ \\
\hline Si 50 Cd 100 & $61,35 \pm 0,50 \mathrm{c}$ & $11,05 \pm 0,19 b$ \\
\hline Si $100 \mathrm{Cd} 0$ & $68,26 \pm 0,29 f$ & $14,60 \pm 0,01^{\mathrm{e}}$ \\
\hline Si $100 \mathrm{Cd} 50$ & $66,96 \pm 0,33^{f}$ & $12,27 \pm 0,31^{c}$ \\
\hline Si $100 \mathrm{Cd} 100$ & $63,55 \pm 1,46^{d}$ & $11,15 \pm 0,52^{b}$ \\
\hline
\end{tabular}

Ket. Angka pada kolom dan baris diikuti huruf yang sama menunjukkan tidak berbeda nyata berdasarkan uji DMRT $(p \geq 0,05)(r=3)$.

a)

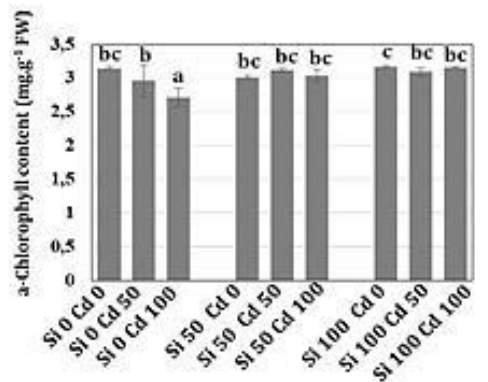

b)

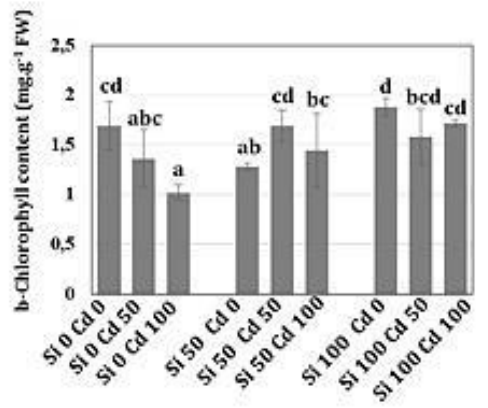

c)

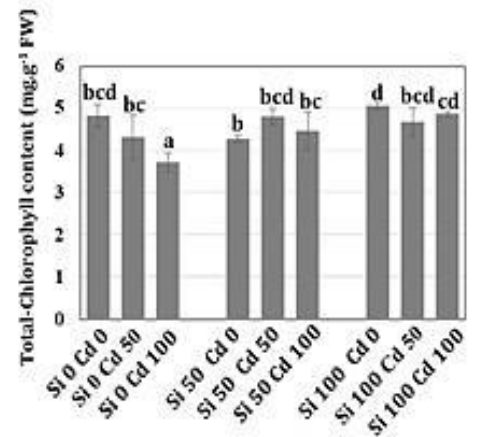

Gambar 1. a) kadar klorofil a; b) kadar klorofil b; dan c) kadar klorofil total (mg.g-1 BB) daun padi 'Cempo Merah' dengan perlakuan Si dan Cd. Ket. Angka pada kolom dan baris diikuti huruf yang sama menunjukkan tidak berbeda nyata berdasarkan uji DMRT $(p \geq 0,05)$. 
Gambar 1. menunjukkan kadar klorofil a, b, dan total (mg.g-1 BB) pada daun padi 'Cempo Merah' dengan perlakuan Si dan Cd. Hasil penelitian menunjukkan bahwa cekaman Cd (100 mg.kg-1 tanah) mereduksi kadar klorofil a dan klorofil total $(\mathrm{p} \leq 0,05)$. Aplikasi Si pada padi yang tercekam Cd (100 mg.kg-1 tanah) secara signifikan $(\mathrm{p} \leq 0,05)$ meningkatkan kadar klorofil baik klorofil a, b, maupun total, Meskipun demikian, tidak terdapat perbedaan yang nyata $(\mathrm{p} \geq 0,05)$ antara dosis Si (50 dan 100 mg.kg-1 tanah). Kadar klorofil a, b dan total tertinggi ditunjukkan oleh perlakuan Si 100 mg.kg-1 tanah tanpa aplikasi Cd.

Padi yang tercekam Cd (50 mg.kg-1 tanah) mengalami penurunan kadar klorofil a, b, dan total, masing-masing sebesar 5,73\%; 19,53\%; dan $10,56 \%$, sementara padi yang tercekam Cd (100 mg.kg-1 tanah) mengalami penurunan kadar klorofil a, b, dan total, masing-masing sebesar 13,69\%; 39,64\%; dan 22,7\%. Semakin tinggi kadar Cd, kadar klorofil semakin menurun, dibandingkan dengan kontrol. Pengaruh $\mathrm{Cd}$ terhadap penurunan kadar klorofil telah dilaporkan pada berbagai macam spesies tanaman seperti tiga kultirvar gandum (Triticum aestivum L.) yaitu Xihan1 (XH), Longzhong1 (LZ) and Dingfeng16 (DF) (He et al., 2020) dan tanaman rami (Boehmeria nivea (L.) Gaud.) (Tang et al., 2015).

Cekaman Cd menurunkan laju fotosintesis dengan cara mempengaruhi komponenkomponen yang terlibat dalam fotosintesis, seperti struktur kloroplas, pigmen fotosintesis, fotosistem, sistem transpor elektron, dan jalur reduksi $\mathrm{CO}_{2}$ (Parmar et al., 2013). Cd dapat menghambat biosintesis klorofil dengan cara mengganggu aktivitas enzim biosintesis klorofil dan menurukan ketersediaan $-\delta$-aminolevulinic acid (ALA), yakni komponen penting dalam biosintesis klorofil (Parmar et al., 2013). Dengan demikian, cekaman Cd menyebabkan penurunan kadar klorofil pada tanaman.

Silikon (Si) merupakan salah satu unsur benefisial yang menstimulasi pertumbuhan dan berkembangan tanaman dan juga berperan dalam pertahanan tanaman ketika menghadapi berbagai macam cekaman (Luyckx et al., 2017). Gejala defisiensi dan toksisitas Si jarang ditemui di alam sehingga selama ini Si dianggap tidak memiliki pengaruh dalam proses metabolisme tanaman. Pada abad ke-20, penelitian mengenai peranan Si dalam menstimulasi pertumbuhan dan perkembangan mulai dilakukan. Beberapa penelitian menunjukkan bahwa $\mathrm{Si}$ dapat mengurangi gejala toksisitas akibat berbagai macam stress atau cekaman baik biotik maupun abiotik pada tanaman (Ma et al., 2011).

Unsur Si diserap dalam bentuk asam orthosilikat $\left(\mathrm{H}_{4} \mathrm{SiO}_{4}\right.$ atau $\left.\mathrm{Si}(\mathrm{OH})_{4}\right)$ oleh sel-sel akar secara pasif yang diatur oleh aliran transpirasi melalui xilem (Malhotra et al., 2016). Padi tergolong akumulator Si (Rao \& Susmitha, 2017). Si dapat diserap oleh akar padi secara aktif melalui transporter Si yang terdapat di membran sel-sel eksodermis dan endodermis akar, yaitu influx transporter OsLsi1 (low silicon 1) dan selanjutnya oleh efflux transporter OsLsi2, asam silikat ditranspor menuju stele dan ditranslokasikan di tajuk secara cepat melalui aliran transpirasi (Ma et al., 2011; Rao \& Susmitha, 2017). Selanjutnya, Si terdeposisi di dalam jaringan epidermis daun sebagai asam monosilikat yang terpolimerisasi dan membentuk gel silika $\left(\mathrm{SiO}_{2}\right.$ amorphous terhidrasi dengan molekul air $\left.\left(\mathrm{SiO}_{2} \cdot \mathrm{nH}_{2} \mathrm{O}\right)\right)$. Selain itu, Si dapat berasosiasi dengan pektin dan ion $\mathrm{Ca}^{2+}$, membentuk lapisan tipis membran selulosa dan silika (Meena et al., 2014). Hal ini mengindikasikan bahwa adanya struktur tersebut dapat meningkatkan rigiditas sel, memperkuat struktur tanaman, menjadikan tajuk lebih tegak dan melindungi tanaman dari stres biotik dan abiotik. Silika amorphous dapat terpresipitasi di sel-sel tanaman membentuk struktur yang disebut phytoliths ( Rao \& Susmitha, 2017).

Hasil penelitian menunjukkan bahwa perlakuan Si meningkatkan tinggi tanaman (Tabel 2). Cuong et al. (2017) juga melaporkan bahwa tinggi tanaman padi meningkat seiring meningkatnya dosis Si yang diberikan meskipun tidak signfikan. Adanya deposisi Si di dalam dinding sel jaringan epidermis dapat meningkatkan tinggi tanaman karena daun dan batang menjadi lebih tegak. Selain itu, Si menstimulasi penyerapan nutrien esensial lainnya yang diperlukan tanaman seperti N, P, K sehingga aplikasi $\mathrm{Si}$ dapat menstimulasi pertumbuhan. Selain tinggi tanaman, pemberian Si juga meningkatkan jumlah anakan dan daun padi baik yang tercekam maupun tidak tercekam Cd (Tabel 2). Peran Si dalam meningkatkan jumlah anakan padi telah diteliti oleh Cuong et al. (2017) dan Pati et al. (2016).

Hasil penelitian menunjukkan bahwa Si (100 mg.kg-1 tanah) mampu meningkatkan pertumbuhan vegetatif dan kadar klorofil $a, b$, dan total pada tanaman padi 'Cempo Merah' yang tercekam Cd (50 dan 100 mg.kg-1 tanah) (p $\leq 0,05)$. Temuan ini sejalan dengan penelitian Kabir et al. (2016) dan LU et al. (2018) yang melaporkan bahwa penambahan $\mathrm{Si}$ dapat meningkatkan pertumbuhan dan kadar klorofil pada tanaman Alfafa (Medicago sativa L.) dan tembakau (Nicotiana tabacum L.).

Salah satu mekanisme Si dalam mengurangi gejala toksisitas Cd yaitu dengan cara mereduksi bioavailibilitas $\mathrm{Cd}$ pada medium pertumbuhan (Dong et al., 2019). Penyerapan Cd oleh akar dipengaruhi oleh beberapa faktor, seperti $\mathrm{pH}$ 
tanah, konsentrasi $\mathrm{Cd}$ di dalam tanah, bioavailabilitas $\mathrm{Cd}$, potensial redoks, material organik, dan konsentrasi unsur-unsur lainnya (Liu et al., 2015). Pada penelitian ini, aplikasi Si tampak tidak mempengaruhi $\mathrm{pH}$ tanah, ditunjukkan dengan $\mathrm{pH}$ tanah pada semua perlakuan yang sama dan cenderung netral $(6,8-7)$. Penelitian Naeem et al. (2015) menunjukkan hasil yang serupa bahwa aplikasi kalsium silikat (150 mg.kg1 tanah) dapat mengimobilisasi $\mathrm{Cd}$ dan menurunkan ketersediaan $\mathrm{Cd}$ tanpa mempengaruhi $\mathrm{pH}$ tanah ( $\mathrm{pH}$ tanah berkisar 7-8).

Peran Si lainnya dalam mereduksi toksisitas Cd pada tanaman yaitu membentuk pertahanan fisik (apoplas) di sel-sel akar, menstimulasi sekuestrasi kompleks phytochelatine-Cd ke dalam vakuola sel-sel akar sehingga mengurangi translokasi Cd dari akar ke tajuk, dan meningkatkan aktivitas antioksidan baik enzimatik maunpun non enzimatik (Malhotra et al., 2016; Bhat et al., 2019). Selain itu, peran Si dalam efektifitas penyerapan nutrien dapat menjadi kunci mengapa pertumbuhan padi 'Cempo Merah' yang diberi Si baik pada kondisi tercekam Cd maupun tidak tercekam Cd, semakin meningkat seiring meningkatnya konsentrasi Si.

\section{Simpulan dan Saran}

\section{Simpulan}

Logam berat Cd (100 mg.kg-1 tanah) memiliki efek negatif dan menyebabkan toksisitas pada padi 'Cempo Merah' dengan menurunkan pertumbuhan vegetatif dan kadar klorofil a, b dan total. Akan tetapi, dampak negatif tersebut dapat dikurangi dengan aplikasi unsur benefisial Si yang terkandung dalam pupuk silikat. Si (100 mg.kg-1 tanah) dilaporkan dapat meningkatkan pertumbuhan vegetatif dan kadar klorofil padi 'Cempo Merah' baik dalam kondisi tidak tercekam maupun tercekam logam berat $\mathrm{Cd}$.

\section{Saran}

Mekanisme Si dalam reduksi toksistas $\mathrm{Cd}$ pada padi dapat terjadi melalui mekanisme eksternal dan internal. Oleh karena itu, saran yang diberikan untuk penelitian selanjutnya yakni melakukan penelitian mengenai kedua mekanisme tersebut secara eksperimental.

\section{Ucapan Terima Kasih}

Peneliti mengucapkan terima kasih kepada Lembaga Pengelola Dana Pendidikan (LPDP) yang telah memberikan dukungan finansial untuk penelitian ini.

\section{Daftar Pustaka}

Bhat, J. A., Shivaraj, S. M., Singh, P., Navadagi, D. B., Tripathi, D. K., Dash, P. K., Solanke, A. U., Sonah, H., \& Deshmukh, R. (2019). Role of silicon in mitigation of heavy metal stresses in crop plants. Plants, 8(3), 1-20. https://doi.org/10.3390/plants8030071

Cuong, T. X., Ullah, H., Datta, A., \& Hanh, T. C. (2017). Effects of silicon-based fertilizer on growth, yield and nutrient uptake of rice in tropical zone of Vietnam. Rice Science, 24(5), 283-290. https://doi.org/10.1016/j.rsci.2017.06.002

Da-lin, L., Kai-qi, H., Jing-jing, M., Wei-wei, Q., Xiuping, W., \& Shu-pan, Z. (2011). Effects of cadmium on the growth and physiological characteristics of sorghum plants. African Journal of Biotechnology, 10(70), 1577015776. https://doi.org/10.5897/AJB11.848

Dong, Q., Fang, J., Huang, F., \& Cai, K. (2019). Silicon amendment reduces soil $\mathrm{Cd}$ availability and Cd uptake of two Pennisetum species. International Journal of Environmental Research and Public Health, 16(9), 1-13. https://doi.org/10.3390/ijerph16091624

Farooq, M. A., Detterbeck, A., Clemens, S., \& Dietz, K. J. (2016). Silicon-induced reversibility of cadmium toxicity in rice. Journal of Experimental Botany, 67(11), 3573-3585. https://doi.org/10.1093/jxb/erw175

Gao, L., Chang, J., Chen, R., Li, H., Lu, H., Tao, L., \& Xiong, J. (2016). Comparison on cellular mechanisms of iron and cadmium accumulation in rice: prospects for cultivating Fe-rich but Cd-free rice. Rice, 9(1). https://doi.org/10.1186/s12284-0160112-7

Grzeszczuk, M., Salachna, P., \& Meller, E. (2018). Changes in photosynthetic pigments, total phenolic content, and antioxidant activity of salvia coccinea Buc'hoz Ex Etl. Induced by exogenous salicylic acid and soil salinity. Molecules, 23(6), 1-11. https://doi.org/10.3390/molecules230612 96

Guo, Q., Meng, L., Zhang, Y. N., Mao, P. C., Tian, X. X., Li, S. S., \& Zhang, L. (2017). Antioxidative systems, metal ion homeostasis and cadmium distribution in Iris lactea exposed to cadmium stress. Ecotoxicology and Environmental Safety, 139(August 2016), 
50-55.

https://doi.org/10.1016/j.ecoenv.2016.12. 013

He, C., Ding, Z., Mubeen, S., Guo, X., Fu, H., \& Xin, G. (2020). Evaluation of three wheat (Triticum aestivum L.) cultivars as sensitive $\mathrm{Cd}$ biomarkers during the seedling stage. PeerJ, 2020(1), 1-16.

https://doi.org/10.7717/peerj.8478

Hossain, M. A., Piyatida, P., da Silva, J. A. T., \& Fujita, M. (2012). Molecular mechanism of heavy metal toxicity and tolerance in plants: central role of glutathione in detoxification of reactive oxygen species and methylglyoxal and in heavy metal chelation. Journal of Botany, 2012(Cd), 1-37. https://doi.org/10.1155/2012/872875

Irfan, M., Ahmad, A., \& Hayat, S. (2014). Effect of cadmium on the growth and antioxidant enzymes in two varieties of Brassica juncea. Saudi Journal of Biological Sciences, 21(2), 125-131. https://doi.org/10.1016/j.sjbs.2013.08.001

Kabir, A. H., Hossain, M. M., Khatun, M. A., Mandal, A., \& Haider, S. A. (2016). Role of silicon counteracting cadmium toxicity in Alfalfa (Medicago sativa L.). Frontiers in Plant Science, 7(JULY2016), 1-12. https://doi.org/10.3389/fpls.2016.01117

Kaushik, P., \& Saini, D. K. (2019). Silicon as a vegetable crops modulator-a review. Plants, 8(6), 1-18. https://doi.org/10.3390/plants8060148

Lin, H., Fang, C., Li, Y., Lin, W., He, J., Lin, R., \& Lin, W. (2016). Effect of silicon on grain yield of rice under cadmium-stress. Acta Physiologiae Plantarum, 38(7), 1-13. https://doi.org/10.1007/s11738-0162177-8

Liu, K., Lv, J., He, W., Zhang, H., Cao, Y., \& Dai, Y. (2015). Major factors influencing cadmium uptake from the soil into wheat plants. Ecotoxicology and Environmental Safety, 113, 207-213. https://doi.org/10.1016/j.ecoenv.2014.12. 005

Lu, H., Li, Z., Wu, J., Shen, Y., Li, Y., Zou, B., Tang, Y., \& Zhuang, P. (2017). Influences of calcium silicate on chemical forms and subcellular distribution of cadmium in Amaranthus hypochondriacus L. Scientific Reports, 7(May 2016), 1-9. https://doi.org/10.1038/srep40583

LU, Y., MA, J., TENG, Y., HE, J., CHRISTIE, P., ZHU, L., REN, W., ZHANG, M., \& DENG, S. (2018). Effect of Silicon on Growth, Physiology, and Cadmium Translocation of Tobacco (Nicotiana tabacum L.) in CadmiumContaminated Soil. Pedosphere, 28(4), 680689. https://doi.org/10.1016/S10020160(17)60417-X

Luyckx, M., Hausman, J. F., Lutts, S., \& Guerriero, G. (2017). Silicon and plants: Current knowledge and technological perspectives. Frontiers in Plant Science, 8(March), 1-8. https://doi.org/10.3389/fpls.2017.00411

Ma, J. F., Yamaji, N., \& Mitani-Ueno, N. (2011). Transport of silicon from roots to panicles in plants. Proceedings of the Japan Academy Series B: Physical and Biological Sciences, 87(7), 377-385. https://doi.org/10.2183/pjab.87.377

Malhotra, C., Kapoor, R. T., \& Ganjewala, D. (2016). Alleviation of abiotic and biotic stresses in plants by silicon supplementation. Scientia Agriculturae, 13(2).

https://doi.org/10.15192/pscp.sa.2016.13. 2.5973

Meena, V. D., Dotaniya, M. L., Coumar, V., Rajendiran, S., Ajay, Kundu, S., \& Subba Rao, A. (2014). A case for silicon fertilization to improve crop yields in tropical soils. Proceedings of the National Academy of Sciences India Section B - Biological Sciences, 84(3), 505-518.

https://doi.org/10.1007/s40011-0130270-y

Muradoglu, F., Gundogdu, M., Ercisli, S., Encu, T., Balta, F., Ze Jaafar, H., \& Zia-Ul-Haq, M. (2015). Cadmium toxicity affects chlorophyll a and b content, antioxidant enzyme activities and mineral nutrient accumulation in strawberry. Biological Research, 48, 3-9.

https://doi.org/10.1186/s40659-0150001-3

Naeem, A., Saifullah, Ghafoor, A., \& Farooq, M. (2015). Suppression of cadmium concentration in wheat grains by silicon is related to its application rate and cadmium accumulating abilities of cultivars. Journal of the Science of Food and Agriculture, 95(12), 2467-2472. https://doi.org/10.1002/jsfa.6976 
Nazar, R., Iqbal, N., Masood, A., Khan, M. I. R., Syeed, S., \& Khan, N. A. (2012). Cadmium toxicity in plants and role of mineral nutrients in its alleviation. American Journal of Plant Sciences, 03(10), 1476-1489. https://doi.org/10.4236/ajps.2012.310178

Parmar, P., Kumari, N., \& Sharma, V. (2013). Structural and functional alterations in photosynthetic apparatus of plants under cadmium stress. Botanical Studies, 54(1), 45. https://doi.org/10.1186/1999-3110$54-45$

Pati, S., Pal, B., Badole, S., Hazra, G. C., \& Mandal, B. (2016). Effect of silicon fertilization on growth, yield, and nutrient uptake of rice. Communications in Soil Science and Plant Analysis, 47(3), 284-290. https://doi.org/10.1080/00103624.2015.1 122797

Rachmawati, D., Luh, N., Mona, G., Tumbuhan, L. F., Biologi, F., Mada, U. G., Pascasarjana, P., Biologi, P. S., Biologi, F., \& Mada, U. G. (2018). Potensi abu sekam padi untuk meningkatkan ketahanan oksidatif nonenzimatik dan produksi padi merah pada cekaman kekeringan. Jurnal Agronomi Indonesia, 46(1), 24-32.

Rao, G. B., \& Susmitha, P. (2017). Silicon uptake, transportation and accumulation in Rice. Journal of Pharmacognosy and Phytochemistry, 6(6), 290-293. http://www.phytojournal.com/archives/?y ear $=2017 \&$ vol $=6 \&$ issue $=6 \&$ ArticleId $=2091$ $\&$ si $=$ false

Robertsa, T. L. (2014). Cadmium and phosphorous fertilizers: The issues and the science. Procedia Engineering, 83, 52-59. https://doi.org/10.1016/j.proeng.2014.09. 012

Supriyanti, A., Supriyanta, \& Kristamtini. (2015). Karakterisasi dua puluh padi (Oryza sativa. L.) Lokal di Daerah Istimewa Yogyakarta. Vegetalika, 4(3), 29-41.

Tang, H., Liu, Y., Gong, X., Zeng, G., Zheng, B., Wang, D., Sun, Z., Zhou, L., \& Zeng, X. (2015). Effects of selenium and silicon on enhancing antioxidative capacity in ramie (Boehmeria nivea (L.) Gaud.) under cadmium stress. Environmental Science and Pollution Research, 22(13), 9999-10008. https://doi.org/10.1007/s11356-0154187-2
Tjitrosoepomo, G. (2007). Morfologi Tumbuhan. Gadjah Mada University Press.

Tripathi, D. K., Singh, V. P., Kumar, D., \& Chauhan, D. K. (2012). Rice seedlings under cadmium stress: Effect of silicon on growth, cadmium uptake, oxidative stress, antioxidant capacity and root and leaf structures. Chemistry and Ecology, 28(3), 281-291. https://doi.org/10.1080/02757540.2011.6 44789

Tubana, B. S., Babu, T., \& Datnoff, L. E. (2016). A review of silicon in soils and plants and its role in us agriculture: History and future perspectives. Soil Science, 181(9-10), 393411.

https://doi.org/10.1097/SS.000000000000 0179

Wardhani, E., Roosmini, D., \& Notodarmojo, S. (2017). Pencemaran kadmium di sedimen waduk Saguling Provinsi Jawa Barat. Jurnal Manusia Dan Lingkungan, 23(3), 285. https://doi.org/10.22146/jml.18802

Wijayanti, T. (2017). Profil pencemaran logam berat pada perairan daerah aliran sungan (DAS) Grindulu Pacitan. JURNAL ILMIAH SAINS, 17(1), 19. https://doi.org/10.35799/jis.17.1.2017.15 057

Xue, Z., Gao, H., \& Zhao, S. (2014). Effects of cadmium on the photosynthetic activity in mature and young leaves of soybean plants. Environmental Science and Pollution Research, 21(6), 4656-4664. https://doi.org/10.1007/s11356-0132433-z 